\title{
Management of pleural sepsis in Nigerian children
}

\author{
CHIJIOKE H ANYANWU AND MARTIN EGBUE
}

From the Cardiothoracic Unit, Department of Surgery, University of Nigeria Teaching Hospital, Enugu, Nigeria

ABSTRACT Pleural sepsis in children is common in most developing countries. It may present as total pyothorax, pyopneumothorax, or localised thoracic empyema. In most cases, it follows ari attack of bronchopneumonia, but other debilitating conditions such as measles, malnutrition, and sickle cell anaemia form part of the clinical syndrome. In a review of 60 cases of pleural sepsis in children aged between 1.5 months and 16 years, there were 40 cases of pyothorax, 15 of pyo $-\frac{-}{>}$ pneumothorax, and five of localised empyema. Treatment with chemotherapy only was given ing. 22 cases of whom eight died. Twenty-three patients had chemotherapy and tube drainage of the pleural contents; five died. Fifteen children had excision of the pleural disease, and decortication of the lung; none died. In view of the chronicity of the pleural sepsis by the time the child is seen in the hospital, and also the low mortality and shorter period in hospital, thoracotomy and decortication is recommended as the treatment of choice.

Pleural sepsis in children may result from several infective processes prominent among which is bronchopneumonia. In its chronic stage, pleural sepsis may appear clinically as thoracic empyema, pyopneumothorax, chest wall abscess, chest wall sinus or as secondary osteomyelitis of a rib. These conditions are no longer common in the developed countries, but in developing countries like Nigeria, they represent serious clinical problems. This is because of the high incidence of infective respiratory diseases ${ }^{12}$ and inadequate medical facilities. Conservative (non-surgical) or surgical methods of management have been advocated by previous authors. $^{3-5}$ In this paper, a review of 60 cases of pleural sepsis at the University of Nigeria Teaching Hospital (UNTH), Enugu is made in order to determine the pattern of this disease complex and evaluate the methods of treatment adopted.

\section{Patients}

The case records of 60 children with pleural sepsis admitted to the children's wards of the UNTH, Enugu between July 1975 and July 1977 were studied. The clinical features, the methods

Address for reprint requests: Dr CH Anyanwu, Cardiothoracic Unit, Department of Surgery, University of Nigeria Teaching Hospital, Enugu, Nigeria. of management, and the results obtained were analysed.

The ages of the 60 children were between 1.5 months and 16 years; $24(56.6 \%)$ of the childrerp? were 12-35 months old. The male : female ratiot was $1 \cdot 3: 1$. The main symptoms were cough, fevero dyspnoea, loss of appetite, and chest pain; in $1 \stackrel{0}{\alpha}$ children the symptoms had lasted for over 21 days? and in 26 children for over 28 days before attend ance at the hospital. The predominant physica何 signs were dyspnoea at rest, pyrexia, diminished chest movement, dullness on percussion or hyper음 resonance (in pyopneumothorax), anaemia, hepato $\Rightarrow$ splenomegaly, marasmus, and scoliosis. The diag․ㅡㄹ. nosis was made from physical signs, chest radiogs raphy, and needle thoracentesis in all except one case which was diagnosed at necropsy. Forty cases were pyothorax, 15 children had pyopneumow thorax, and five had localised empyema. Associate diseases in some children are shown in table Measles was a predisposing condition in 10 case $\$$ of pyothorax, four cases of pyopneumothorax, and one case of localised empyema. Malaria was not specifically investigated.

Two-thirds of the patients had haemoglobif levels of $10 \mathrm{~g} / \mathrm{dl}$ or less; about half of these chip dren with low haemoglobin levels had sickle ce trait or disease. Bacteriological cultures of pleurat aspirates or tissues from 51 cases were positive 通 
Table 1 Associated clinical conditions

\begin{tabular}{ll}
\hline Condition & Number of cases \\
\hline Measles & 15 \\
Marasmus & 6 \\
Gastroenteritis & 6 \\
? Pulmonary tuberculosis & 4 \\
Congestive cardiac failure & 3 \\
Pericardial effusior & 2 \\
Chronic otitis media & 2 \\
Pyomyositis & 2 \\
Congenital heart disease & 1 \\
Chickenpox & 1 \\
Sickle cell disease & 1 \\
\hline
\end{tabular}

Table 2 Types of micro-organism isolated from 34 cases

\begin{tabular}{|c|c|c|c|c|}
\hline Micro-organism & Pyothorax & $\begin{array}{l}\text { Pyopneumo- } \\
\text { thorax }\end{array}$ & $\begin{array}{l}\text { Localised } \\
\text { empyema }\end{array}$ & Total \\
\hline Staph aureus & 10 & 3 & 2 & 15 \\
\hline E coli & 5 & 2 & - & 7 \\
\hline$B$ proteus & 3 & $\overline{1}$ & 1 & 5 \\
\hline $\begin{array}{l}\text { Ps aeruginosa } \\
\text { Strep }\end{array}$ & 2 & 2 & 1 & 5 \\
\hline $\begin{array}{l}\text { pneumoniae } \\
\text { Kleb }\end{array}$ & - & 1 & 一 & 1 \\
\hline pneumoniae & 1 & - & - & 1 \\
\hline Total & 21 & 9 & 4 & 34 \\
\hline
\end{tabular}

34 cases $(66.7 \%)$. Table 2 shows the types of micro-organism isolated. In four cases, including the two with empyema sinuses, mixed organisms were found.

\section{Treatment}

The methods of treatment adopted for the different types of pleural sepsis and the results obtained are summarised in table 3 . Twenty-two children had chemotherapy only; eight died. Intramuscular or intravenous ampicillin $(50-100 \mathrm{mg} / \mathrm{kg}$ ), ampicillin plus cloxacillin $(25-50 \mathrm{mg} / \mathrm{kg})$, and crystalline penicillin $(50-100 \mathrm{mg} / \mathrm{kg})$ six-hourly for up to 14 days were the most commonly used antibiotics. Other antibiotics were used when necessary and available. Surgical treatment was advised in five

Table 3 Methods of treatment and results

\begin{tabular}{|c|c|c|c|c|c|c|c|}
\hline \multirow[t]{2}{*}{ Treatment } & \multicolumn{2}{|c|}{ Pyothorax } & \multicolumn{2}{|c|}{$\begin{array}{l}\text { Pyopneumo- } \\
\text { thorax }\end{array}$} & \multicolumn{2}{|c|}{$\begin{array}{l}\text { Localised } \\
\text { empyema }\end{array}$} & \multirow[t]{2}{*}{ Total } \\
\hline & Alive & Dead & Alive & Dead & Alive & Dead & \\
\hline $\begin{array}{l}\text { Chemotherapy } \\
\text { only }\end{array}$ & 11 & 7 & 0 & 0 & 3 & 1 & 22 \\
\hline $\begin{array}{l}\text { Tube drainage }+ \\
\text { chemotherapy }\end{array}$ & 11 & 3 & 7 & 2 & 0 & 0 & 23 \\
\hline $\begin{array}{l}\text { Thoracotomy } \\
\text { decortication }\end{array}$ & 8 & 0 & 6 & 0 & 1 & 0 & 15 \\
\hline Total & 30 & 10 & 13 & 2 & 4 & 1 & 60 \\
\hline
\end{tabular}

cases of pyothorax and one case of localised empyema but the advice was not accepted by the parents. Medical treatment lasted between 15 and 93 days (mean 31.6 days).

Drainage of the pleural space by tube thoracostomy was performed in 19 cases of pyothorax with three deaths, and in 13 cases of pyopneumothorax with two deaths. Five cases of pyothorax and four of pyopneumothorax subsequently underwent thoracotomy and decortication. The amount of purulent fluid drained varied between $300 \mathrm{ml}$ and $4000 \mathrm{ml}$, and was over $1000 \mathrm{ml}$ in the majority. The duration of tube drainage was from one to 29 days (average 12.4 days). Accidental extrusion of the tube occurred in eight patients. Other complications of tube drainage were inadequate drainage, persistent lung collapse, reaccumulation of pus, and iatrogenic pneumothorax.

Fifteen cases (eight of pyothorax, six of pyopneumothorax, and one of localised empyema) were treated by thoracotomy, excision of the pleural disease, and decortication of the lung. They included nine cases in whom tube drainage had failed. Two of these children were aged under 3 months. None died. The main operative findings are shown in table 4; fibrothorax was present in $66.7 \%$ of these cases. Complications after decortication were wound infection in four cases, and wound dehiscence requiring secondary suture in one. The hospital stay after decortication was between eight and 18 days (average 11 days).

During a follow-up period of up to three and a half years, no significant complication and no death has been recorded in any of the cases treated surgically.

\section{Discussion}

Pleural sepsis in children is usually secondary to infective processes elsewhere, but chiefly in the lungs. In addition to bacterial bronchopneumonia, trauma, tuberculosis, actinomycosis, and amoebic liver abscess are other aetiological factors. These

Table 4 Findings at thoracotomy

\begin{tabular}{ll}
\hline Finding & Number \\
\hline Fibrothorax & 10 \\
Thick pus & 9 \\
Necrotic slougn & 6 \\
Bronchopleural fistula & 3 \\
Emphysematous cysts & 2 \\
Enlarged hilar lymph nodes & 2 \\
Rib sequestrum & 1 \\
Hypoplastic right upper lobe & 1
\end{tabular}


disease conditions are now rare in the developed countries. Over a 13-year period, Le Roux ${ }^{6}$ found only 25 cases of empyema in children aged up to 10 years, while Groff ${ }^{4}$ reported 23 cases in childhood in a five-year period. But in the developing countries like Nigeria, chronic pleural sepsis in childhood is common. ${ }^{78}$ Moreover, in these countries, measles, anaemia from other causes, malnutrition, malaria, sickle cell disease, and gastroenteritis complicate the clinical progress and management of the pleural sepsis. The presence of these associated diseases may also lead to initial misdiagnosis of the pleural sepsis-"bronchopneumonia with measles or kwashiorkor" is not an uncommon diagnosis. Though tuberculosis still exists in Nigeria, it could not be confirmed bacteriologically in any of the four cases suspected to be of tuberculous origin. Malaria is endemic in our environment and antimalarials are therefore given routinely to the children on admission. The association between malaria and pleural sepsis in children is, however, being studied. Our patients generally tend to attend the hospitals in the late stages of illness. This is because most patients initially resort to self-medication, or consult the "traditional healers" or street chemists/pharmacists who may treat them for days or weeks. Moreover, antibiotics are readily obtainable from market stalls and street chemists without a doctor's prescription. Therefore, there is usually a long history of symptoms in most of our cases of pleural sepsis in children, though the parents may not readily admit it. This contrasts with the short history of the patients of other authors ${ }^{4}$; it also influenced the management and prognosis in our cases. Our $66.7 \%$ rate of positive bacterial culture is higher than the $50 \%$ expected by Russell. ${ }^{5}$ Staph aureus remains the most common organism isolated in childhood post-pneumonic pleural sepsis. The rarity of the pneumococcus and the relatively high incidence of the coliforms reflect the changed pattern of bacterial infections in children.

The method of management of our cases depended on (a) early diagnosis, (b) severity of the disease, (c) associated diseases, (d) availability of therapeutic facilities including appropriate antibiotics, drainage tubes, and bottles, and operating theatre space.

Chemotherapy was given to all the 60 cases and it was the only method of treatment in 22 cases, especially in the early part of the period under review and before a full thoracic surgical service was available. The high mortality $(36.4 \%)$ in this group of medically treated cases, emphasises the

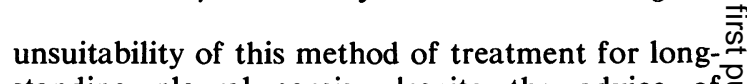
standing pleural sepsis, despite the advice of Russell $^{5}$ for "several months of conservative $\frac{\bar{c}}{\bar{c}}$ therapy, physiotherapy and observation." The $\overrightarrow{\mathbb{\Phi}}$ choice of antibiotics for our patients depended on the availability of the individual antibiotic, and the bacterial sensitivity tests on the pleural aspirates. $\overrightarrow{0}$ The antistaphylococcal agents, ampicillin and cloxacillin, were commonly used. Chlorampheni- $\bar{o}$ col, though cheap (and readily abused), is not $\nRightarrow$ used routinely in children because of its toxic ${ }_{\omega}^{x}$ effects. Facilities for anaerobic cultures are inade- $\%$ quate; metronidazole is not often used for bacterial infection in our children, although it is used $\mathbb{N}_{N}$ for amoebic liver disease especially in adults.

Surgical treatment by thoracentesis (needle or tube) for pyothorax or pyopneumothorax, is a simple and effective procedure that could be per-을. formed by most doctors in hospitals lacking $\vec{\oplus}$ thoracic surgeons. It can be life-saving in the severely distressed child. Disposable thoracic ${ }^{-}$ catheters with trocars have been found useful foro this method of treatment. However, because of the high mortality $(21.7 \%$ in this series) and the complications of tube drainage, we now adopt this $\frac{\mathscr{Q}}{\mathbb{Q}}$ procedure as an emergency measure only in most 2 cases while preparations are made for thoracotomy. $\overrightarrow{\overrightarrow{0}}$

Thoracotomy with excision of the pleural 3 disease and decortication of the lung is the treatment of choice if facilities, including trained and? experienced staff, are available. The chronicity of the pleural sepsis when the children present, and the possibilities of complications such as drug resistance, septicaemia, bronchopleural fistula, fibro-3. thorax and chest deformities, ${ }^{9}$ chronic chest sinus, and osteomyelitis of a rib, make early excision and decortication advisable. Fourteen of ouro patients were found at thoracotomy to have thick pus or necrotic slough or both which would makeo tube drainage of the pleural contents a futile procedure. Other workers ${ }^{30^{-12}}$ have also advocatedô aggressive surgical management by early decorti- $\sim$ cation. Our patients were discharged earlier from the hospital after decortication than after con-o servative treatment. In a country like Nigeria where there is a deficiency of hospital beds especially for children, this shorter period of inpatient? treatment is of great advantage. Because of the chronicity of the pleural sepsis, and the advantageso of shorter hospitalisation, decortication would have been appropriate for most of our cases, but because $\overrightarrow{0}$ of inadequate theatre facilities and a limited bloodo transfusion service it could be applied in only $25 \%$

In addition to the management of the pleurap sepsis, the treatment of associated diseases such 
as gastroenteritis, anaemia, malaria, skin sepsis, otitis media, and malnutrition is essential. The morbidity and mortality in these children with pleural sepsis are increased significantly by the presence and severity of these extrapleural diseases. This study indicates that with adequate facilities, in a developing country like Nigeria, thoracotomy with excision of the pleural disease and decortication of the lung is the treatment of choice. We have adopted this policy in subsequent cases of chronic pleural sepsis presenting as pyothorax, pyopneumothorax, or localised empyema.

We are grateful to Dr TC Okeahialam, Dr W Kaine, Dr JC Azubuike, Dr EO Okoroma, and Dr Ike Izuora, consultant paediatricians, for referring most of these cases to our unit, and to Miss Diane Atuh for secretarial assistance.

\section{References}

1 Morley DC. Paediatric priorities in the developing world. London: Butterworths, 1973:202.

2 Kaine WN, Okolie JB. A review of the causes of hospitalisation as a guide to pattern of disease amongst children in Eastern Nigeria. Niger Med J 1977; 7:205-9.
3 Middlekamp JN, Purkerson ML, Burford TH. The changing pattern of empyema thoracis in pediatrics. J Thorac Cardiovasc Surg 1964; 47: 165-73.

4 Groff DB, Randolph JG, Blades B. Empyema in childhood. JAMA 1966; 195:572-4.

5 Russell G. In: Textbook of paediatrics. Forfar JO, Arneil FC, eds. Edinburgh and London: Churchill Livingstone, 1973:574-5.

6 Le Roux BT. Empyema thoracis. Br J Surg 1965; 52:89-99.

7 Farpour A, Sajedee M. Empyema in paediatric patients in Iran. Am J Surg 1967; 114:856-61.

8 Aderele WI, Stevenson CE, Antia AU. Empyema in childhood: a review of 116 cases. Niger J Paediatr 1974; 1:20-5.

9 Barrett NR. The pleura with special reference to fibrothorax. Thorax 1970; 25:515-24.

10 Morin JE, Munro DD, Maclean LD. Early thoracotomy for empyema. J Thorac Cardiovasc Surg 1972; 64:530-6.

11 Fishman MH, Ellertson DG. Early pleural decortication for thoracic empyema in immunosuppressed patients. J Thorac Cardiovasc Surg 1977; 74:537-41.

12 Ravitch $M$, Fein $R$. The changing picture of pneumonia and empyema in infants and children. JAMA 1961; 175:1039-44. 